\title{
IMPACT OF DISPLAY AND HANDLING ON THE CHEMICAL AND MICROBIAL CONTENT OF BEEF FROZEN LIVER
}

\author{
NEHAD, I.E. SALEM ${ }^{1}$; GEHAN, I. E. ALI ${ }^{2}$; NEHAL, A.A. NAENA ${ }^{3}$ and \\ MAYADA, A.M. ABOU ZEID ${ }^{3}$ \\ ${ }^{1}$ Regional Kafr El-Sheikh Animal Health Research Institute, Department of Food Hygiene. \\ ${ }^{2}$ Regional Kafr El-Sheikh Animal Health Research Institute, Department of Biochemistry. \\ ${ }^{3}$ Regional Kafr El-Sheikh Animal Health Research Institute, Department of Bacteriology.
}

Received: 19 January 2017; $\quad$ Accepted: 21 March 2017

\begin{abstract}
A total of 60 beef frozen liver samples from different market retail from different origins in Kafr-El-sheikh Governorate were collected then transferred immediately to the laboratory under aseptic conditions. These collected samples were subjected to chemical, bacteriological and mycological analysis. The obtained results revealed that the mean values of $\mathrm{pH}$ and TVN-B (Total Volatile Nitrogen) in examined frozen liver samples were $5.54 \pm 0.01$ and $6.99 \pm 0.28 \mathrm{mg} / 100 \mathrm{gm}$, respectively. While in microbial analysis the Staphylococcus aureus was isolated from 44 samples (66.7\%), and there were two strains have the ability to produce enterotoxins (A), only one strain can produce enterotoxine (B), one strain can produce enterotoxine (B\&D) and one strain produce enterotoxine (A\&D). The percentage of other Staphylococci were Staph saprophyticus (12.5\%), Staph epidermidis (23.8\%), Staph intermedius (7.5\%) and Staph capitis $(2.5 \%)$. Also the mold were isolated from $80 \%$ from the examined frozen liver samples and the isolated mold strains were identified as 24 A.niger $(26.1 \%), 10$ A. flavus (10.9\%), 8 A. fumigatus (8.7\%), 10 Penicillium (10.9\%), 6 Fusarium Spp. (6.5\%), 6 Rhizopus Spp. (6.5\%), 6 Mucor Spp. (6.5\%), 6 Thamnidium Spp. (6.5\%), 4 Nigrospora Spp.(4.3\%) and 2 Trichothecium Spp. (2.2\%). Multiplex PCR was done to detect the virulence of isolated strains of A.flavus and found that the Lane(1) was Positive A. flavus strain for nor-1 and omtA genes, Lane(2) was Positive A. flavus strain for nor-1, ver-1, omtA and aflR genes, Lane(3) was Positive A. flavus strain for nor-1 gene, Lane(4) was Positive A. flavus strain for nor-1, ver-1 and aflR genes and Lane(5) was Positive A. flavus strain for nor-1, ver-1 and omtA genes. In conclusion, the obtained results indicate that consumption of frozen liver may cause a public health hazard to the consumer. Measures to control the quality of beef frozen liver during display and handling should be taken.
\end{abstract}

Key words: Handling, Chemical, Microbial, Beef, Frozen Liver.

\section{INTRODUCTION}

Beef liver is a very popular meal in developing countries especially for Egyptian due to its high and beautiful taste. The last 30 years have seen major changes in the offal trading globally. So the present study was planned to estimate the quality of the beef frozen liver consignment on the basis of the Egyptian Organization for Standardization and quality (EOS).

Liver is an edible meat by-product that has high nutritional value as it contain high biological value of protein, iron and zinc (Doornebal and Murray, 1981) and (Marchello et al., 1985). Also it constitutes about $1-2 \%$ of live weight in bovine (Ockerman, 1988). The liver tissue spoil faster than meat which cause

Corresponding author: Dr. NEHAD, I.E. SALEM

E-mail address: nournabil18@yahoo.com

Present address: Regional Kafr El-Sheikh Animal Health Research Institute, Department of Food Hygiene practical problems when trading, handling and reaching to consumer and is exposed to many of critical points through which it exposed to pollutants Physical, chemical and microbial in different forms, leading to deterioration of their quality and spoilage (Al-Dughaym and Altabari, 2010).

The liver is the largest organ in the body which possesses a great variety of nutrients and act as an excellent source of high quality animal protein, fat and carbohydrates. In addition, it is a generous supply of certain vitamins and minerals. And it is easily deteriorated, so it necessitates specific care during handling and preservation to improve its quality and protect human health. The proximate composition of liver is moisture $(71.92 \%)$, protein $(18.44 \%)$, fat $(5.60 \%)$ and carbohydrate (2.72). Mineral concentration ( $\mathrm{mg} \%)$ in liver are sodium (60.04), potassium (274), calcium (5.60), magnesium (6.20), iron (20.86) and copper (5.60) (Tollefson and Miller, 2000). 
Egypt imports large quantities of beef frozen liver from United States of America and other countries. And many problems lead to hindering the international flow of liver trade and most of them were confined to the shelf-life issue which in the Egyptian standards is seven months (Lee et al., 2000), the initial microflora of raw meat consists of different microorganisms that break down proteins; fats and carbohydrates results in spoilage of meat reduced its shelf-life and public health hazards (Liu et al., 2013 and Phillips et al., 2006).

Presence of spoilage bacteria is responsible for unfavorable changes or pathogenic bacteria leading to harmful effects, as food infection or intoxication among consumers (Eley, 1992). Organoleptic, chemical and microbiological quality of meat and edible offal have been receiving attention, all over the world, from researchers, food industry, health organization and governments due to the occurrence of significant outbreaks of food borne illness affecting consumers. So quality maintenance is important for consumer health (Baumann-Popczyk and Sadkowska-Todays, 2012).

\section{MATERIALS AND METHODS}

\section{Preparation of samples (EOS/ 63-2001):}

The frozen liver samples were thawed by holding it in refrigerator overnight at $5^{\circ} \mathrm{c}$ and examined. The sample was taken from 3 different areas at least from each sample, and then minced very well insuring good homogeneity. The prepared samples were kept in a sealed glass container to prevent the leak of humidity and air inside. All the steps were carried out under hygienic conditions and then subjected to the following examinations:

\section{A-Chemical analysis:}

1. Determination of pH (Pearson, 1984):

In a blender, approximately $10 \mathrm{~g}$ of samples were blended in $10 \mathrm{ml}$ of distilled water. The homogenate was left at room temperature for $10 \mathrm{~min}$ with continuous shaking. The $\mathrm{pH}$ value was determined by using an electrical pH meter (Bye model 6020, USA).

\section{Determination of Total Volatile Basic Nitrogen (TVB-N mg/100 gm):}

The technique applied for determination of total volatile nitrogen (TVB-N) was recommended by Food and Agriculture Organization (FAO, 1980). TVB-N mg/100 gm = 26.88 x (2-T2)

Where, $\mathrm{T} 2=$ volume of $\mathrm{NaOH}$ consumed in the titration

\section{B-Bacteriological examination:}

1- Isolation of Staph. aureus: according to (FDA, 2002).

2- Identification of Staphylococci species:

\section{2-1. Morphological examination (Cruickshank et} al., 1975):

Films were prepared from a pure culture of the isolated microorganism stained with Gram's stain and then examined microscopically. Staphylococci appeared as Gram positive cocci resembling grape like clusters.

\section{2-2 Biochemical identification (MacFaddin, 2000):}

\section{A- Catalase activity test:}

The purified suspected colonies were picked up with a sterile loop and transferred into the surface of glass slide. Accurately, one or two drops of hydrogen peroxide solution (3\%) were added then the cover slide was applied. The rapid appearance of gas bubbles was considered a positive reaction. S. aureus gives +ve result.

\section{B- Oxidase test:}

Oxidase test was done by streaking of the pure culture onto filter paper moistened with oxidase reagent. The test is positive if the color turns to mauve, violet or deep purple within 10 seconds. S. aureus gives -ve result.

\section{C- Growth at $6.5 \% \mathrm{NaCl}$ :}

Series of sterile peptone water was produced with salt $(\mathrm{NaCl})$ concentration $6.5 \%$. Suspension with the suspected colony was prepared to be identified and each of the tubes with loopful was lightly inoculated and incubated at $37^{\circ} \mathrm{C}$ for $24 \mathrm{~h}$. The turbidity indicates that the suspected colony could grow at such concentration of sodium chloride. S. aureus gives +ve result.

\section{D- Detection of Arginine decarboxylase (ADH).}

Suspected colonies were inoculated into arginine decarboxylase medium just below the surface. One $\mathrm{ml}$ of sterile mineral oil was added to the top of the medium and incubated at $37^{\circ} \mathrm{C}$ for $24 \mathrm{~h}$. Turbidity and violet color indicate a positive ADH. S. aureus gives +ve result.

\section{E- Bile esculin test:}

A loopful from isolated organism was inoculated into test tube containing Bile esculin agar slant which incubated at $37^{\circ} \mathrm{C}$ for $24 \mathrm{~h}$. If an organism can hydrolyze esculin, the media will turn dark brown or black. However, the test is interpreted as a positive result only if more than half the medium is dark brown or black after incubation. S. aureus gives -ve result.

\section{F- Mannitol test:}

Suspected colonies were subcultured on mannitol salt agar plates and incubated at $37^{\circ} \mathrm{C}$ for $24 \mathrm{~h}$. Staph aureus showed yellow colonies surrounded by a halo zone. S. aureus gives +ve result (gas formation). 


\section{G- Detection of haemolysis:}

A loopful from inoculated brain heart infusion (BHI) broth were streaked on the surface of sheep blood agar plates and incubated at $37^{\circ} \mathrm{C}$ for $24 \mathrm{~h}$ for detection of haemolysis.

\section{H- Coagulase test:}

Accurately, $0.1 \mathrm{ml}$ from BHI broth cultures were transferred to Wassermann tubes containing $0.3 \mathrm{ml}$ of sterile reconstituted rabbit plasma (or human plasma). Inoculated tubes were incubated at $37^{\circ} \mathrm{C}$ for $24 \mathrm{~h}$. The tubes were examined for clotting (fibrin clot formation). The extent of coagulase reaction was recorded. Tubes were left at room temperature for an additional $20 \mathrm{~h}$ and then re-examined for clot formation. The extent of coagulation of the plasma was reported after 4 and 24 h. Staph aureus gives +ve result.

\section{I- Thermo stable nuclease test "D-Nase activity"} (Lachia et al., 1971):

D-Nase agar plates were inoculated with loopfuls of suspected colonies by spotting them on small areas of the plates which incubated at $37^{\circ} \mathrm{C}$ for $18 \mathrm{~h}$. Moreover, the incubated plates were flooded with normal hydrochloric acid which precipitated DNA resulting in cloudiness of the plates. Accordingly, Appearance of a clear zone around the colony indicated the production of D Nase and recorded as positive result.

\section{J- Fermentation of sugars:}

To $5 \mathrm{ml}$ peptone water $(1 \%)$ containing $0.2 \%$ bromocresol purple indicator, $1 \%$ of the following sugars were added (lactose, mannitol, arabinose, ribose, sorbitol and raffinose). Durham's tubes were inverted into the test tubes for a collection of a gas. After incubation at $37^{\circ} \mathrm{C}$, the reaction of the inoculated tubes was noticed every day for 7 successive days. Appearance of pink color indicates positive result.

3. Detection and typing of Staph aureus enterotoxins: it was carried out according to (Oda et al., 1979) and (Shingaki et al., 1981).

The isolated $S$. aureus strains were examined for their ability to produce enterotoxins using Staphylococcal Enterotoxin-Reverse Passive Latex Agglutination kit (SET-RPLA) and Sac culture method.

C-Mycological examination: It was carried out according to Bailary and Scott (1998).

The molds were isolated by cultivation on sabouroaud media and incubated at $25^{\circ} \mathrm{C}$ for $2-5$ days.

\section{Identification of isolated molds:}

According to their morphological characters, mold colonies were picked up with their surrounding medium under aseptic conditions and transferred to Sabouraud Dextrose agar slopes and incubated at $25^{\circ} \mathrm{C}$ for 7 days for further identification. Identification of mold genera and species was carried out according to Raper and Fennell (1965) and Samson (1979) for genus Aspergillus, ARX (1967); Raper and Thom (1969); Samson et al. (1976) and Zycha et al. (1969) for the other mold genera.

\section{D-Multiplex Polymerase Chain Reaction (PCR):}

\section{Primer sequences used for Multiplex PCR identification system:}

The demonstration of virulence factors including norsolonic acid reductase (nor), versicolorin A (ver1), O-methylsterigmatocystin (omtA) and transcription regulator (aflR) as aflatoxin producing genes of the isolated A. flavus strains was carried out using the following primers:

\begin{tabular}{|c|c|c|c|c|}
\hline Primer & $\begin{array}{c}\text { Target } \\
\text { gene }\end{array}$ & Oligonucleotide sequence $\left(5^{\prime} \rightarrow 3^{\prime}\right)$ & $\begin{array}{l}\text { Product } \\
\text { size (bp) }\end{array}$ & References \\
\hline nor-1 (F) & & 5' ACCGCTACGCCGGCACTCTCGGCAC '3 & & \multirow{8}{*}{$\begin{array}{l}\text { Criseo et al. } \\
\quad(2001)\end{array}$} \\
\hline nor-1 (R) & aflD & 5' GTTGGCCGCCAGCTTCGACACTCCG '3 & 400 & \\
\hline ver-1 $(\mathrm{F})$ & \multirow[b]{2}{*}{ aflM } & 5' GCCGCAGGCCGCGGAGAAAGTGGT '3 & \multirow[b]{2}{*}{537} & \\
\hline ver-1 (R) & & 5' GGGGATATACTCCCGCGACACAGCC '3 & & \\
\hline omtA (F) & \multirow{2}{*}{ aflP } & 5' GTGGACGGACCTAGTCCGACATCAC '3 & \multirow{2}{*}{797} & \\
\hline omtA (R) & & 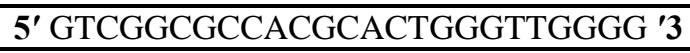 & & \\
\hline aflR (F) & \multirow{2}{*}{ aflR } & $\mathbf{5}^{\prime}$ TATCTCCCCCGGGCATCTCCCGG '3 & \multirow{2}{*}{1032} & \\
\hline aflR $(\mathrm{R})$ & & 5' CCGTCAGACAGCCACTGGACACGG '3 & & \\
\hline
\end{tabular}

\section{DNA Extraction (Erami et al., 2007):}

The strains of identified A. flavus were grown for $72 \mathrm{~h}$ under continuous shaking conditions in the Potato Dextrose Broth. The mycelium was then harvested by filtration, transferred to a mortar, frozen in liquid nitrogen and ground to a powder which was resuspended in a lysis buffer $(50 \mathrm{mmol} / \mathrm{L}$ EDTA, $0.2 \% \mathrm{SDS}, \mathrm{pH}=8.5)$ and heated immediately at $68^{\circ} \mathrm{C}$ for $15 \mathrm{~min}$. After centrifugation for $15 \mathrm{~min}$ at 15000 rpm, $10 \mathrm{ml}$ volume of the supernatant fluid was transferred to a new centrifuge tube and $1 \mathrm{ml}$ of 4 mol/L sodium acetate was added. This solution was placed on ice for $1 \mathrm{~h}$ and centrifuged for $15 \mathrm{~min}$ at $15000 \mathrm{rpm}$. After centrifugation, the supernatant fluid was transferred to a fresh tube and extracted by 
Genomic DNA extraction Kit (Bioshop ${ }^{\circledR}$ Canda Inc., Canada).

3. DNA amplification for the selected virulent genes (Davari et al., 2015):

The amplification was performed on a Thermal Cycler (Master cycler, Eppendorf, Hamburg, Germany). All of the isolated A. flavus and $A$. parasiticus were examined for the presence of four important aflatoxin genes (nor-1, ver-1, omtA and aflR) enclosed in the aflatoxin biosynthesis pathway by multiplex PCR using the above mentioned 4 primer sets. PCR reaction was performed in $25 \mu \mathrm{L}$ containing $2.5 \mu \mathrm{L} 1 \times$ PCR buffer, $0.75 \mu \mathrm{L} 50$
mMMgcl2, $0.5 \mu \mathrm{L} 10 \mathrm{mM}$ dNTPs, $2 \mu \mathrm{L}$ of each primer, $0.2 \mu \mathrm{L} \mathrm{Taq}$ DNA polymerase $(1 \mathrm{U} / \mu \mathrm{L}), 5 \mu \mathrm{L}$ extracted DNA as template and $8.05 \mu \mathrm{L}$ sterile distilled water. The PCR cycling protocol was applied as following: A total of 35 cycles was started with heating at $94^{\circ} \mathrm{C}$ for $5 \mathrm{~min}$, and continued by denaturation for $30 \mathrm{~s}$ at $94^{\circ} \mathrm{C}$, annealing for $30 \mathrm{~s}$ at $67^{\circ} \mathrm{C}$, elongation for $30 \mathrm{~s}$ at $72^{\circ} \mathrm{C}$ and a final extension of $10 \mathrm{~min}$ at $72^{\circ} \mathrm{C}$. Amplified products were electrophoresed in $1 \%$ agrose gel (Sigma-USA) stained with ethidium bromide and visualized and captured on UV transilluminator. A 100 bp DNA ladder was used as a marker for PCR products.

\section{RESULTS}

Table 1: Chemical analysis of beef frozen liver samples $(n=60)$.

\begin{tabular}{cccc}
\hline Chemical parameters & Minimum & Maximum & Mean \pm S.E \\
\hline pH & 5.37 & 5.73 & $5.54 \pm 0.01$ \\
\hline TVN $\mathbf{m g} / \mathbf{1 0 0 g m}$ & 2.97 & 11.86 & $6.99 . \pm 0.28$ \\
\hline
\end{tabular}

Table 2: Incidence of Staph. aureus in examined beef frozen liver samples.

\begin{tabular}{ccccc}
\hline No. of samples & +ve samples & $\%$ & -ve samples & $\%$ \\
\hline 60 & 44 & 66.7 & 16 & 26.7 \\
\hline
\end{tabular}

Table 3: Identification of Staphylococci in examined beef frozen liver samples. (No. of isolates=74).

\begin{tabular}{ccc}
\hline Identified strain & No. & $\%$ \\
\hline S. saprophyticus & 20 & 27 \\
\hline S. epidermidis & 38 & 51.4 \\
\hline S. intermedius & 12 & 16.2 \\
\hline S. capitis & 4 & 5.4 \\
\hline Total & 74 & 100 \\
\hline
\end{tabular}

Table 4: Coagulase reaction and enterotoxins production of staph aureus in examined beef frozen liver samples.

\begin{tabular}{cclc}
\hline Identified bacterium & No. of isolate & Further identification & Enterotoxin \\
\hline Staph aureus & 2 & Coagulase +ve/DNase +ve & A \\
\hline Staph aureus & 1 & Coagulase +ve/DNase +ve & B \\
\hline Staph aureus & 1 & Coagulase +ve/DNase +ve & B\&D \\
\hline Staph aureus & 1 & Coagulase +ve/DNase +ve & A\&D
\end{tabular}

Table 5: Incidence of mold in examined beef frozen liver samples.

\begin{tabular}{ccccc} 
No. of samples & +ve samples & $\boldsymbol{\%}$ & -ve samples & $\boldsymbol{\%}$ \\
\hline 60 & 48 & 80 & 12 & 20 \\
\hline
\end{tabular}


Table 6: Identification of mould species in positive samples. (No. of identified isolates=82).

\begin{tabular}{ccc}
\hline Identified strain & No. of isolates & \% \\
\hline A.niger & 24 & 29.3 \\
\hline A.flavus & 10 & 12.2 \\
\hline A.fumigatus & 8 & 9.8 \\
\hline Penicillium & 10 & 12.2 \\
\hline Fusarium & 6 & 7.3 \\
\hline Rhizopus Spp. & 6 & 7.3 \\
\hline Mucor Spp. & 6 & 7.3 \\
\hline Thamnidium Spp. & 6 & 7.3 \\
\hline Nigrospora Spp. & 4 & 4.9 \\
\hline Trichothecium & 2 & 2.4 \\
\hline Total & 82 & 100 \\
\hline
\end{tabular}

The percentage was calculated according to total isolates.

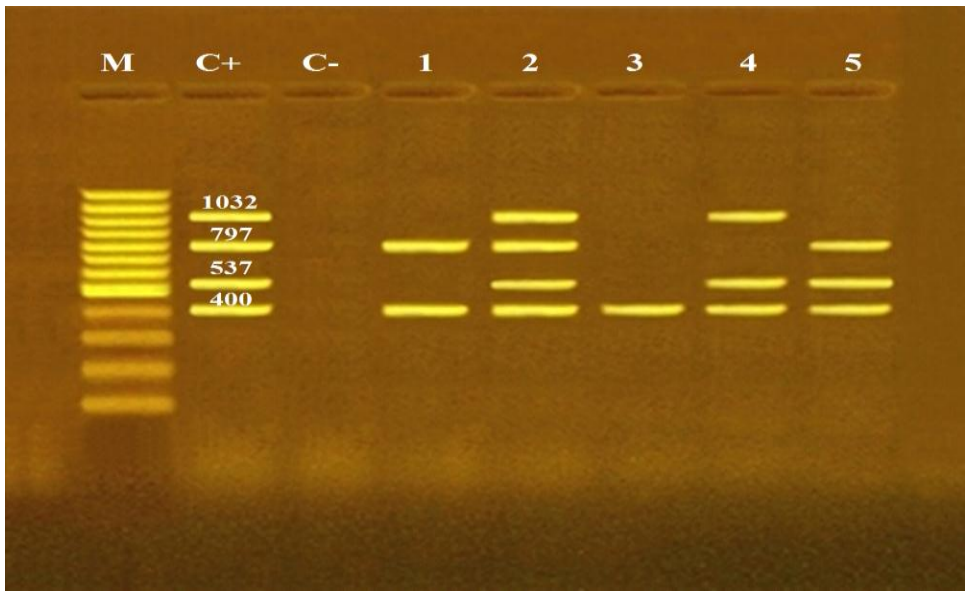

Photograph (1): Agarose gel electrophoresis of multiplex PCR of nor-1 (400 bp), ver-1 (537 bp), omtA (797 bp) and aflR (1032 bp) virulence genes for characterization of Aspergillus flavus.

Lane M: 100 bp ladder as molecular size DNA marker.

Lane C+: Control positive strainfor nor-1, ver-1, omtA and aflR genes.

Lane C-: Control negative.

Lane 1: Positive A. flavus strain for nor-1 and omtA genes.

Lane 2: Positive A. flavus strain for nor-1, ver-1, omtA and aflR genes.

Lane 3: Positive A. flavus strain for nor-1 gene.

Lane 4: Positive A. flavus strain for nor-1, ver-1 and aflR genes.

Lane 5: Positive A. flavus strain for nor-1, ver-1 and omtA genes.

\section{DISCUSSION}

Freezing and frozen storage of meat produce profound effect on its structural and chemical properties including changes in muscle fibers, lipid and protein. These changes significantly influencing the quality attributes of them. ICMSF (1998), frozen meat is likely to be under go changes of physical and chemical properties leading to effect on nutritive value and eating quality which is the most important for consumer acceptance, Miller et al. (1999). In table
(1) the results showed that $\mathrm{pH}$ values of the examined frozen liver samples ranged from 5.37 to 5.73 with mean of $5.54 \pm 0.01$. These results of $\mathrm{pH}$ were relatively lower than that recorded by Ondin et al. (2015) with mean value of 6.143, El-Tokhey (1980) reported $\mathrm{pH}$ values ranged between 6.0 to 6.2., Salem (1992) reported $\mathrm{pH}$ values ranging from 5.65 to 6.19 and Mohie El-din (2000) reported the minimum, maximum and mean value of $\mathrm{pH}$ of imported frozen liver samples were 5.85, 6.20 and 6.06, respectively. 
$\mathrm{Ph}$ is considered one of the most critical parameters in meat and meat product quality as it determines their shelf life and functional properties (Florek et al., 2012).

EOS/ 1473 (2007) mentioned the $\mathrm{pH}$ value of frozen liver is range from 5.5 to 6.2.So.all these samples according to these range were within the acceptable limits stipulated by these standards. The rise of the meat $\mathrm{pH}$ values at frozen storage period may be due to the possible breakdown of proteins and consequently the increase of ammonia and free amino group produced in meat (Davey and Gilbert, 1968 and Cuzzoni and Gazzoni, 1984).

In the same Table the results of TVN-B of examined samples ranged from $2.97 \mathrm{mg} / 100 \mathrm{~g}$ to $11.86 \mathrm{mg} / 100 \mathrm{~g}$ with mean of $6.99 \pm 0.28 \mathrm{mg} / 100 \mathrm{gm}$. These results were lower than that recorded by Ondin et al. (2015) who recorded that the mean value of TVN-B was $28.484 \mathrm{mg} / 100 \mathrm{gm}$.

Ammonia is one of the most spoilage end products in spoiled meat and meat products which is directly responsible for spoilage odors and flavors, it is considered as an indicator for amino acid degradation by bacteria and it can be measured as total volatile basic nitrogen (Gill, 1983). Accordingly, TVB-N can be considered as a reliable indicative measure for the quality of various food articles. The TVB-N mean values showed that all the examined samples were accepted according to the safe permissible limit recommended by EOS (2005) for TVB-N in edible offal (should not exceed $30 \mathrm{mg} / 100 \mathrm{gm}$ ). Furthermore, TVB-N value was more useful for assessing the degree of meat deterioration than for evaluating the changes occurring during the first storage stages (El Marrakchi et al., 1990).

In Table (2) the results showed that the Staph.aureus could be isolated from $44(66.7 \%)$ from the examined samples, while in Table (3) further identification were done for other Staphylococci and the results revealed that the percentage of staph saprophyticus, staph epidermidis, staph intermedius and staph capitis were $12.5,23.8,7.5$, and 2.5 respectively.

In table (4) the results cleared that there were five strains from staph aureus Coagulase +ve/DNase +ve produced enterotoxine (A), (B), (B\&D) and (A\&D). Coagulase positive Staphylococcus is considered as an indicator of poor hygiene/handling procedures, staph aureus enterotoxins are considered one of the common causes of food poisoning worldwide, with outbreaks caused by mishandling of foods after heat treatment, (Soriano et al., 2002 and Kadariya et al., 2014). Although, cooking destroys the bacteria, the toxin produced by staph aureus is heat stable and may not be destroyed even by heating, Ghosh et al. (2004). Staph aureus enterotoxins are the predominant cause of gastrointestinal symptoms observed during intoxications. Staph aureus is considered the third most important cause of disease in the world amongst the reported food-borne illnesses (Tamarapu et al., 2001). Staph aureus entered into the foods during handling, processing or vending. It also due to the fact that it forms the normal microflora present on the skin and in the nose and throat of most healthy people. So contamination of foods with coagulase- positive staphylococci is largely as a result of human contact (Nester et al., 2001).

In Table (5) the results showed that the molds could be isolated from $48(80 \%)$ from the examined samples, while in table (6) the results showed further identification for molds and revealed that A.niger, A.flavus, A.fumigatus, Penicillium, Fusarium, Rhizopus Spp., Mucor Spp., Thamnidium Spp., Nigrospora Spp. and Trichothecium were represented by percentage (26.1), (10.9), (8.7), (10.9), (6.5), (6.5), (6.5), (6.5), (4.3) and (2.2), respectively.

Moulds can grow over an extremely wide range of temperatures. They can assist in the putrefactive processes and may produce toxic substances namely mycotoxins which may lead to hemorrhages with hepatotoxic, carcinogenic or immunosuppressive effects (Hassan et al., 2004). As molds induce certain undesirable changes as off flavors, color defects and actual rots. Also certain molds have the ability to produce mycotoxins which are implicated in some cases of food poisoning and liver cancer. (Mossel, 1982 and Varshney et al., 1991).

The Aspergillus, Fusarium and Penicillium molds are among the most important in producing mycotoxins detrimental to cattle. (Lon and Winston, 2005) and (Reddy et al., 2010).

Photograph (1) Showed the Agarose gel electrophoresis of multiplex PCR of nor-1 (400 bp), ver-1 (537 bp), omtA (797 bp) and aflR (1032 bp) virulence genes for characterization of Aspergillus flavus and found Lane (1) was Positive A. flavus strain for nor-1 and omtA genes, Lane (2) was Positive A. flavus strain for nor-1, ver-1, omtA and aflR genes, Lane (3) was Positive A. flavus strain for nor-1 gene, Lane (4) was Positive A. flavus strain for nor-1, ver-1 and aflR genes and Lane (5) was Positive A. flavus strain for nor-1, ver-1 and omtA genes.

Aflatoxins are a group of structurally-related toxic compounds produced by certain strains of the fungi Aspergillus flavus and A.parasiticus. (Ayhan et al., 2010).

Since the toxin-producing mold was identified as Aspergillus flavus in 1960 and the toxin was given the name Aflatoxin by virtue of its origin (A. flavus-- 
$>$ Afla). Aflatoxins have sub-acute and chronic effects such as liver cancer, chronic hepatitis, jaundice, hepatomegaly and cirrhosis in humans. (Hampikyan, et al., 2010).

Aspergillus flavus and A. parasiticus are economically important moulds that produce exclusively aflatoxin B1, B2, G1 and G2, and all the other aflatoxins are derivates of these four. The four major naturally produced aflatoxins are known as B1, $\mathrm{B} 2, \mathrm{G} 1$, and $\mathrm{G} 2$. "B" and "G" refer to the blue and green fluorescent colors produced under UV light on thin layer chromatography plates, while the subscript numbers 1 and 2 indicate major and minor compounds, respectively (Felicia et al., 2011).

So $80 \%$ of the examined frozen cow liver samples of were rejected based on their total mould count according to EOS (2005) which stated that meat and edible offal should be free from any fungal growth.

\section{CONCLUSION}

The results of this study indicated that hygienic conditions of beef frozen liver were very poor and could pose a risk for human health after consumption of undercooked cow liver. So restricted measures to control the quality of cow frozen liver during display and handling should be taken.

\section{REFERENCES}

Al-Dughaym, A.M. and Altabari, G.F. (2010): Safety and quality of some chicken meat products in Al-Asha markets-Saudi Arabia. Saudi Journal of Biological Sciences, 17: 37-42. and Hall Publisher, London.

Arx, J.A. Vpm (1967): Pilzkunde, J. Cramer inder A.R. Canter Verlag, Kommanditgesellschaft. FL - 9490 Vaduz.

Ayhan, F.; Sinan, I. and Fusun, T. (2010): Ankara Univ Vet FakDerg, 57, 197-199.

Bailey, W.R. and Scott, E.G. (1998): Diagnostic Microbiology. Text book for isolation and identification of pathogenic organisms. The C.V Mosby Company Sarnt Houis.

Baumann-Popczyk, A. and Sadkowska-Todays, $M$. (2012): Food borne infection and intoxications in Poland in 2010. Przegl Epidemiol., 66 (2): 241-248.

Criseo, G.; Bagnara, A. and Bisignano, G. (2001): Differentiation of aflatoxin-producing and non-producing strain of Aspergillus flavus group. J. App. Microb., 33: 291- 295.

Cruickshank, R.; Duguid, J.; Marmion, B. and Swain, R.H. (1975): Medical Microbiology. $12^{\text {th }}$ Ed., Edinburg, London and New York.

Cuzzoni, M.T. and Gazzani, G. (1984): Storage of frozen beef. Rivistadellasocieta
Italianadiscienzade 11, Olimentazionz, 13(3): 243-248. C.F., FSTA, 17(10): 10S 20 (1985).

Davari, E.; Mohsenzadeh, M.; Mohammadi, G.; Shahsavandi, S. and Doloei, R. (2015): Characterization of aflatoxigenic Aspergillus flavus and A. parasiticus strain isolates from animal feedstuffs in Northeastern Iran. Iranian J. Vet. Res., 16 (2): 150-155.

Davey, C.L. and Gilbert, K.V. (1968): Studies in meat tenderness. The nature of myofibrillar proteins extracted from meat during aging. J. Food Sci., 33: 344-348.

Doornebal, H. and Murray, A.C. (1981): Effects of age, breed, sex and muscle oncertain mineral concentration in cattle. Journal of Food Science, 47, 55-59.

El Marrakchi, A.; Bennour, M.; Bouchriti, N.; Hamama A. and Tagafait, H. (1990): Sensory, chemical and microbiological assessment of Moroccan sardines (Sardinapilchardus) stored in ice. J. Food Protec., 53: 55.

Eley, A.R. (1992): Microbial food poisoning.1st Ed. P.46-51. Champan

El-Tokhey, H. (1980): Studies on spoilage of some meat. M. Agri. Sc. Thesis faculty of Agriculture, Moshtohor, Zagazig University.

EOS (Egyptian Organization for Standardization and Quality Control): No.63-2001. "Chemical tests guide for frozen meat and meat products".

EOS (Egyptian Organization for Standardization and Quality Control): No. 2062-2005. "frozen kidneys, heart, spleen, brain, pancreas and tongue".

EOS (Egyptian Organization for Standardization and Quality Control): No.1473-2007. "Frozen Liver".

Erami, M.; Hashemi, S.; Pourbakhsh, S.; Shahsavandi, S.; Mohammadi, S.; Shooshtari, A. and Jahanshiri, Z. (2007): Application of PCR on detection of afla toxinogenic fungi. Arch. Razi Inst., 62: 95-100.

FDA: Food and Drug Administration (2002): Department of Health and Human Services. Part 582-Substances generally recognized as safe-chemical preservatives. Sec. 582-3640.

Felicia, W.U.; Clare, Narrod; Marites, Tiongco and Yan, Liu (2011): The Health Economics of Afla toxin: Global Burden of Disease, International Food Policy Research Institute 2033 K Street, NW. Washington, DC 200061002 USA.

Florek, M.; Litwinczuk, Z.; Skalecki, P. and Kedzierska, M. (2012): Chemical composition and inherent properties of offal from calves maintained under two production systems. Department of commodity science and animal raw materials processing university of life science in Lublin Poland. Meat science, 90.402-409. 
Food and Agriculture Organization "FAO"(1980): Manual of Food Quality Control. FAO, United Nation, Rome, Italy.

Ghosh, M.; Mudgil, S. and Ganguli, A. (2004): Microbiological quality of carrots used for preparation of fresh squeezed street vended carrot juices in India. J. Food Agric. Environ., 2: $143-145$

Gill, C.O. (1983): Meat spoilage and evaluation of potential storage life of fresh meat. J. Food Prot. 46(5): 444- 452.

Hampikyan, H.; Baris Bingol, E.; Cetin, O. and Colak, H. (2010): Journal of Food Agriculture and Environment, 8

Hassan, A.A.; Ragheb, R.R. and Rahmy, Nariman, A. (2004): Pathologicalchanges in cows spontaneously fed on some mycotoxins. Egypt. J. Comp. Path. And Clinic. Path., 17 (1): 282- 293.

ICMSF: International Commission on Microbiological Sepcification for Foods (1998): Microbial Ecology of Foods Commodities. Vol. I: Factors affecting life and death of m.o. Academic press, Inc., New York.

Kadariya, J.; Smith, T.C. and Thapaliya, D. (2014): Staphylococcus aureus and Staphylococcal Food- Borne Disease: An Ongoing Challenge in Public Health. Bio Med Research International, Article ID 827965, pp: 9.

Lachia, R.; Genigeogis, C. and Hoeprich, P. (1971): Meta chromatie agar- diffusion methods for detecting Staphylococcal nuclease activity. Appl. Microbiol. 21: 585: 587.

Lee, H.J.; Lee, M.H. and Ruy, P.D. (2000): Public health risk: chemical and antibiotic residue. Asian-Aust. J. Anim. Sci. 14: 402-413.

Liu, K.; Lin, X.; Chen, L.; Huang, L.; Cao, S. and Wang, H. (2013): Preparation of microfibrillated cellulose/ChitosanBenzalkonium chloride biocomposite for enhancing antibacterium and strength of sodium alginate films. Journal of agricultural and food chemistry, 61(26), 6562-6567.

Lon, W.W. and Winston, M.H. (2005): Mycotoxins in Dairy Cattle. Occurrence, Toxicity Prevention and Treatment. South west Nutr. Conf.: 124138.

MacFaddin, J.F. (2000): Biochemical tests for identification medical bacteria. Watery Press Inc, Baltimore, Md. 21202 USA.

Marchello, M.H.; Slanger, W.D. and Milne, D.B. (1985): Macro and micro minerals from selected muscles from pork. Journal of Food Science, 50, 1375-1378.

Miller, A.J.; Ackepman, S.A. and Palumbo, S.A. (1999): Effects of frozen storage on functionality of meat for processing. J. Food Sci., 45: 1466-1471.
Mohie El-din, A.M. (2000): Studies on quality and public health hazard of imported liver. Faculty of veterinary medicine, Suez Canal University.

Mossel, D.A.A. (1982): Microbiology off food 3rd Edition, the University of Utrecht, Netherlands ISBN.

Nester, E.W., Anderson, D.G.; Roberts, C.E.; Pearsall, N.N. and Nester, M.T. (2001): Microbiology: A Human Perspective. 3 Ed., cGraw- Hill, NewYork, rd ISBN: 0072318783, pp: 815-816.

Ockerman, H.W. (1988): Edible meat byproducts. In H. W. Ockerman and C. L.Hansen (Eds.), Animal by-product processing (pp. 27-57). Chichester, England: Ellis Harwood International Publishers in Science and Technology.

Oda, T.; Ohkubo, T.; Nagai, M.; Nishimoto, Y. and Ohmoruk, K. (1979): Detection of Staphylococcal enterotoxins in foods by RPLA test.Ann. Rep. Funkauka City, Japan. Hyg. Lab. 4: 33-37.

Ondin Ahmed Selim; Ali Meawad Ahmed and Soad A. oliman (2015): Quality Loss during Frozen Storage Duration of the Imported Frozen Liver. $^{\text {2nd }}$ Conference of Food Safety, Suez Canal University, Faculty of Veterinary Medicine Volume I, Page 135-141.

Pearson, A.M. and Gillette, T.A. (1996): Processed meats. 3rd Ed New, York Albany, Bonn, Boston, London Pikul, J.., Leszezynski, D.E., Kummerow. F. 1983. Elimination of sample auto oxidation by butylated hydroxytoulene."J. Agric. Food Chem. 31: 1338.

Pearson, D. (1984): Chemical Analysis of Foods. 9th Ed, publishing Co. Churchill living stones, Edinburgh, London, United Kingdom.

Phillips, Jordan, D.; Morris, S.; Jenson, I. and Sumner, J. (2006): A national survey of the microbiological quality of beef carcasses and frozen boneless beef in Australia. J. Food Protec., 69 (5): 1113-1117.

Raper, K.B. and Fennell, D.I. (1965): The genus Aspergillus. $1^{\text {st }}$ Ed. Williams and Wilkins Company, Baltimore.

Raper, K.B. and Thom, C. (1969): A manual of the penicillia, Williams and Wilkins Company, Baltimor.

Reddy, K.R.N.; Salleh, B.; Saad, B.; Abbas, H.K.; Abel, C.A. and Sheir, W.T. (2010): An overview of mycotoxin contamination in foods and its implications for human health. Toxin Rev. 29: 3-26.

Salem, A.M. (1992): Biological analytical studies on incipient of beef meat and liver. M.V.Sc. Thesis (Meat Hygiene), Fac. Vet.Med., Moshtohor Zagzig Unv. (Benha Branch).

Samson, R.A. (1979): A complication of Aspergilli. Studies in Mycology 3: 198-202 
Samson, R.A.; Stalk, A. and Hadlok, R. (1976): Revision on the subsection subsection fasiculata of Penicillium and some allied species. Studies in Mycology 2: 75-78.

Shingaki, M.; Igarashi, H.; Fujikawa, H.; Ushioda, H.; Terayrna, T. and Sakai, S. (1981): Study on Reversed Passive Latex Agglutination for detection of staphylococcal enterotoxins A, B, and C. Annu.; Rep. Tokyo, metro p. Res. Lab. Public Health 32(1): 128-131.

Soriano, J.M.; Font, G.; Moltó, J.C. and Mañes, J. (2002): Enterotoxigenic staphylococci and their toxins in restaurant foods. Trends Food Sci. Tech., 13: 60-67.

Tamarapu, S.; McKillip, J.L. and Drake, M. (2001): Development of a multiplex Polymerase chain reaction assay for detection and differentiation of S.aureus in dairy products. J. Food Protec., 64: 664- 668 .

Tollefson, L. and Miller, M.A. (2000): Antibiotic use in the food animals: controlling the human health impact. J. AOAC International, 83(2): 245- 254.

Varshney, J.L.; Agarwal, D.K. and Sarbhoy, A.K. (1991): Mycotoxins contamination of food, its influence on animals, humans and plants, its management. Proc. Sumposium mycotoxins incidence and human health, Bahagalpar, P.P.147.

Zycha, H.; Siepmann, R. and Linnemann, G. (1969): Mucorales. Eine Beschreibung aller Gattungen und Arten dieser Pilzgruppe, von H. Zycha und R. Siepmann. Mit einem Beitrag zur Gattung Mortierella von G. Linnemann. J. Cramer.

\section{تأثثير العرض والتداول على المحتوى الكيميائى والميكروبيولوجى للكبدة البقرى المجمدة \\ نـهاد ابراهيم الدسوقى سالم، جيهان ابراهيم السبل على ، نيهال على عبل الله نعينع ، مبادة عبل الحمبا محد أبوزيا}

Email: nournabil18@yahoo.com Assiut University web-site: www.aun.edu.eg

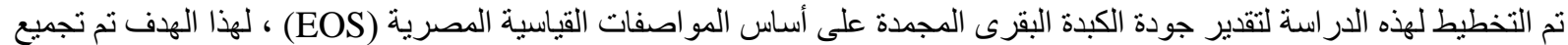

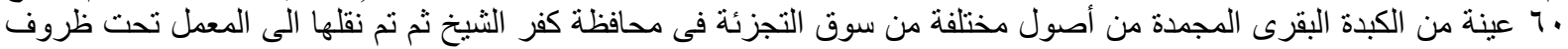

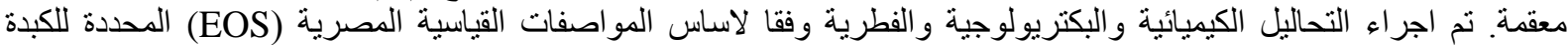
المجمدة. وكثفت النتائج ان متوسط قيم تركيز أيون الهيدروجين (الأس الهيدروجينى) ونسبة المركبات النيتروجينة الطيارة فى عينات

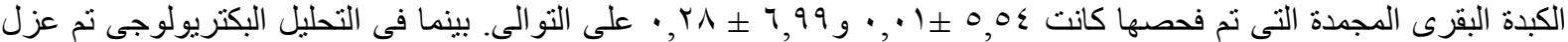

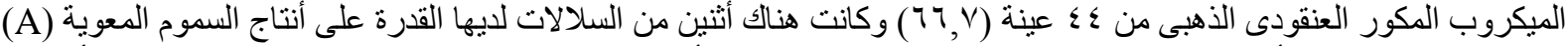

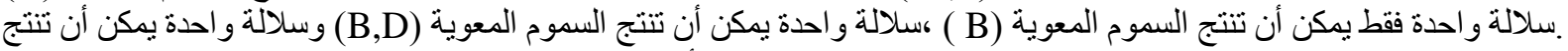

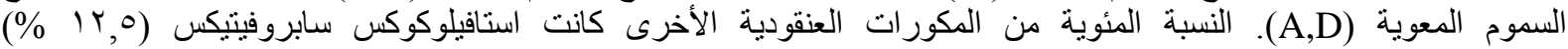

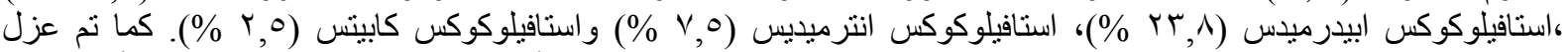

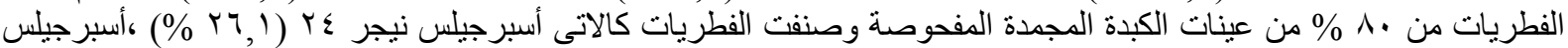

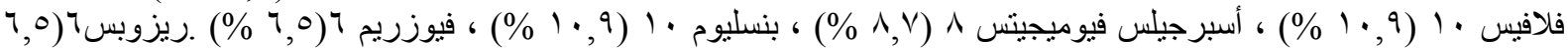

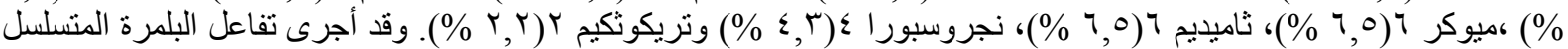

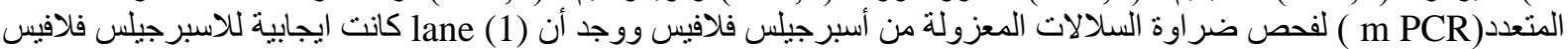

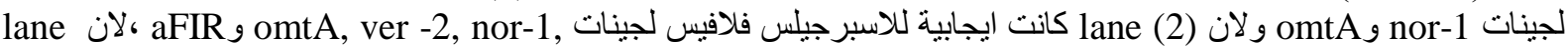

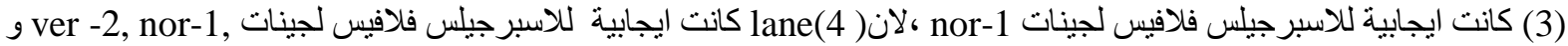

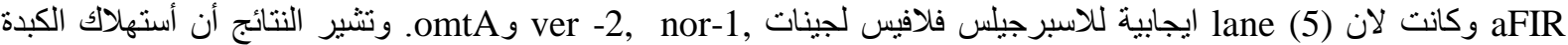

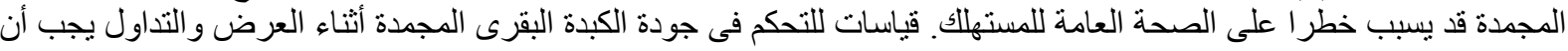

تؤخذ فى الاعتبار. 